\title{
Role of Occupational Stress on Job Satisfaction
}

\author{
Mardhiah Yaacob \\ Choi Sang Long \\ Universiti Teknologi Malaysia \\ Email: mardhiahyaacob@yahoo.com; cslong_1@yahoo.com
}

\section{Doi:10.5901/mjss.2015.v6n2s1p81}

\begin{abstract}
This research was conducted to investigate the relationship between occupational stress and job satisfaction among teachers. The determinants of occupational stress that have been investigated under this study include role ambiguity, role overload, and work-family conflict. The sample consists of a teacher from Malacca. 386 teachers were invited to participate in the questionnaire survey. A cross sectional study was used to examine the relationship between occupational stress and job satisfaction. Descriptive analysis, Pearson correlation and multiple regression analysis were employed to analyse the data. According to the result, the level of role ambiguity and role overload was high. However, there was a moderate level of workfamily conflict. The findings also revealed that there is a significant relationship between occupational stress and job satisfaction. Only role ambiguity has significant relationship with job satisfaction. The result also shows that role ambiguity and role overload were predictor of job satisfaction.
\end{abstract}

Keywords: stress; occupational stress; job satisfaction; role ambiguity; role overload; work-family conflict;

\section{Introduction}

Occupational stress has become one of the most serious health issues in the modern world (Lu et al., 2003). Occupational stress has become one of the most popular topics for applied research in psychology, and in the broader areas of social and medical sciences. Occupational stress, also known as job stress, has been defined as the experience of negative emotional states such as frustration, worry, anxiety and depression attributed to work related factors (Kyriacou, 2001). Occupational stress is also defined as the perception of a discrepancy between environmental demands (stressors) and individual capacities to fulfill these demands (Topper, 2007). Occupational stress, in particular, is the inability to cope with the pressures in a job, because of a poor fit between someone's abilities and his/her work requirements and conditions (Holmlund-Rytkönen and Strandvik, 2005).

According to Jahanzeb (2010), workplace has become a source of extreme stress as a result of technological changes, mass retrenchment, information overload, and demand for greater productivity, fierce competition and uncertain future. So as to keep pace with this competitive world, employees in the work place spend most of their time striving to meet their job obligations hence ignoring the "stressors" that have adverse effects on their domestic, social and personal life. Demands of the work place may prove harmful to the employee both mentally and physically.

Several studies have shown that occupational stress can lead to various negative consequences for the individual and the workplace (Oginska-Bulik, 2006). Extreme stress can lead to decreased productivity and an overall negative impact on the organization itself. People with a higher percentage of occupational stress may not be satisfied with their job and therefore they will not feel happy working in the organization. Therefore, it is very important for employer and employees to realize the stress and the stressor that cause all the negative effects (Bhatti et al., 2011).

This study aims to investigate the relationship between occupational stress and job satisfaction among teachers and to identify the factor that influence teachers' job satisfaction. This study will assist the teachers to identify their occupational stress and give good implications towards their job satisfaction.

\section{Literature Review}

This section looks at the factors that contribute to occupational stress, link between occupational stress and job satisfaction, as well as a conceptual framework and hypothesis. 


\subsection{Factors that contribute to occupational stress}

Teaching can be a very stressful occupation and teacher stress appears to have increased in recent decades (Kyriacou, 2001). In educational sector, stress is increasing day by day because teaching today's young people is not only difficult work, but can be dangerously stressful (Mehta, 2013). Teachers have to cope with their task to give knowledge as well as to educate students to be good citizens. With the increase demand from students and parents, as well as the job requirement by Malaysia's Ministry of Education, the stress levels are readily increasing (Nurul et al., 2010). In Malaysia, a total of 237 primary and secondary teachers out of 36, 000 teachers in the state, sought psychiatric treatment because of stress from work and personal problems over the last 10 months. The Malaysia State Education Department views this matter seriously although the number is smaller. Teachers reported stress out because of work pressure, financial problems, depression and loneliness (Mohd Adib, 2012). Nilufar et al. (2009) identified occupational stress inducing factors in academic staff include work overload, home-work interface, role ambiguity and performance pressure.

The main cause of occupational stress in the organization is work overload (Topper, 2007). Malaysian teachers have raised serious concern about the long working hours reporting an average hours as high as 77 hours per week (Malaysia Education Blueprint, 2012). Teachers being burdened with administrative and clerical work felt it was hard to focus on their core business which is teaching students (Ili Liyana, 2013). Besides, teachers are also engaged in administrative duties that take a large portion of their time resulting in a decrease in their ability to focus on teaching and learning. Sometimes teachers are also asked to attend meetings and courses that are not related to their job and take them away from their classroom. The workload and challenges faced by teachers increase each day and to burden them with more work. This will not go down well especially with the examination period being around the corner (Rutra, 2011). The increase in workload in the organization without taking into account the availability of time to carry out the tasks may lead to occupational stress.

When roles of the teachers are ambiguous, it will leads towards the conflicting demand placed on them and role ambiguity and role conflict are positively associated with the work stress experience by the teachers (Usman et al., 2011). Higher work stress experienced by the teachers, lower will be their satisfaction with their job. According to Usman et al. (2011), teachers experience occupational stress due to the increase performance pressure. They experience role ambiguity where there is conflicting demands placed on them, their role is not very clear as to what to do, what not to do, who to report and what targets are to be achieved and also they have to work longer hours and feel overloaded in their role. Besides, the daily interaction with students and colleagues and the incessant and fragmented demands of teaching often lead to overwhelming pressure and challenges, which may lead to occupational stress (Brown and Uehara, 2008).

Teachers are also under a lot of pressure because of work-family conflict. Teachers must do some work, such as preparing lessons plan for the next day and grading exam papers at home. They have to devote time to their work outside school hours, which result in sacrificing time that could be devoted to housework and their children (Simbula, 2010). This may cause problem known as work-life conflict or work-family conflict. The teachers can satisfy with their jobs and life if they can balance their work and family life. Anyway, work family conflict is one of the problems in modern society (Kappagoda, 2013). The amount of stress a person experience at work is likely to be a result of the interaction of a number of factors such as types of work they are doing (their occupation), the present of work stressors, and the amount of support they received both at work and at home (Johnson et al., 2005).

Several studies found that occupational stress influences the employee's job satisfaction and overall performance in their work (Nilufar et al., 2009; Karadal et al., 2008; Usman et al., 2011). This is because most of the organizations are demanding for employees' better job outcome. Stress can bring undesirable impact on employees through job dissatisfaction (Leather et al., 2003). Teachers are also subject to problems of dissatisfaction at workplace. If they are not satisfied, they may not be committed to deliver the best to achieve the target in teaching (Zainudin et al., 2010). Research done by Antoniou et al. (2003) showed that when sources of stress increase in the job environment, job satisfaction reduces. They also reported that low job satisfaction can be predicted through resources of stress such as demands of the profession and great volume of work. Employees with low occupational stress reported have more job satisfaction than those with high occupational stress (Johnson et al., 2005; Sweeney and Quirin, 2009; Lambert et al., 2009; Sveinsdottir et al., 2006).

\subsection{Link between occupational stress and job satisfaction}

According to some studies (Johnson et al., 2005), employees with low occupational stress have more job satisfaction than employees with high occupational stress. The result of some studies showed that there is a strong negative relationship between occupational stress and job satisfaction (Sweeney and Quirin, 2009; Lambert et al., 2009). Studies 
with the adoption of job satisfaction as an indicator of occupational stress have shown that role overload (Butt and Lance, 2005; Gaither et al., 2008; Correa and Ferreira, 2011), role ambiguity (Koustelios et al., 2004; Karadal et al., 2008; Faucet et al., 2012), and work-family conflict (Lambert et al., 2002; Calvo-Sulguero et al., 2010; Chen et al., 2012) have been shown as a predictors of job satisfaction.

Role overload was demonstrated to be a source of stress which acts as a significant negative predictor of job satisfaction and positive predictor of negative emotions directed to work. A relationship between role overload and job satisfaction has been reported in various occupational groups (Butt and Lance, 2005; Gaither et al., 2008; Zainudin et al., 2010; Correa and Ferreira, 2011; Rai, 2013). According to Correa and Ferreira (2011), people who perceived that they were required to work in a position with demands greater than their own abilities tended to be less satisfied and direct more negative emotions towards their work.

In a study, Kemery (2006) found that, although role conflict and role ambiguity individually had negative relationships with job satisfaction, the combined effect of the two factors on appointment satisfaction was more complex. When role conflict and role ambiguity were both high, appointment satisfaction was low, but when role conflict was low, satisfaction was actually higher when role ambiguity was high. On the other hand, Karadal et al. (2008) analyzed the effect of role conflict and role ambiguity on job satisfaction and organizational commitment. Their findings indicated that both role conflict and role ambiguity were negatively related to employees' job satisfaction and organizational commitment. Their study concluded that managers must reduce the level of role conflict and role ambiguity if they want to increase job satisfaction and organizational commitment.

Work-family conflict has become an issue of particular concern among employees and the negative consequences of this conflict for employee's job satisfaction. There have been researches into the relationship between work-family conflict and job satisfaction. Most studies have found a negative relationship between occupational stress and job satisfaction (Lambert et al., 2002; Lu et al., 2008; Calvo-Salguero et al., 2010; Chen et al., 2012). Lambert et al. (2002) studied found that time-based work-to-family conflict negatively affects job satisfaction. Due to the nature of correctional work (i.e. shift, rotation on weekends/holidays, and job transfer), their study predicts that Taiwanese correctional officers may experience work-family conflict, which in turn could negatively affect their job satisfaction. While, Lu et al. (2008) found that organizational policies and practices such as work flexibility could alleviate feelings of work interfering with family, further enhancing job satisfaction and organizational commitment.

Stress can bring undesirable impacts on employees through creating low organizational commitment and job dissatisfaction (Leather et al., 2003). Antoniou et al. (2003) believed that when sources of stress increase in job environment, job satisfaction reduces. So, job satisfaction has an important role in improving the performance of employees. Consequently, if there are discrepancies between individuals' desires and expectations and condition of their present jobs, negative thoughts and dissatisfaction arise at work.

\subsection{A conceptual framework and hyphothesis}

The conceptual framework for this study is developed based on the objectives and previous literature. The reason to conduct this study is to investigate the relationship between occupational stress and job satisfaction among teachers and to identify the factor that influence teachers' job satisfaction. Their relationships are illustrated in figure 1 below.

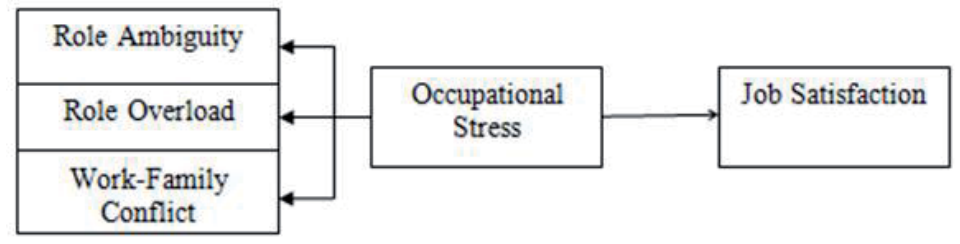

Figure 1: Diagram of the Conceptual Framework

This study infers that there is a relationship between occupational stress and job satisfaction. Based on the above discussion, statement hypothesis is as follows:

$\mathrm{H1}$ : There is significant relationship between occupational stress and job satisfaction

$\mathrm{H} 2$ : There is significant relationship effect between occupational stress (role overload, role ambiguity, and workfamily conflict) and job satisfaction 


\section{Research Methodology}

\subsection{Participants}

This study was conducted in selected school and district in Malacca. A total of 386 teachers were participated in this study. The respondents were 282 female (73.1\%) and 104 males (26.9\%). Majority of them were married (318 respondent or $82.4 \%)$ and 68 respondents (17.6\%) were single. The respondents represented (89.4\%) were Malay, 31 Chinese (8.0\%), and 10 Indian (2.6\%). Majority of teachers have bachelor degree (334 respondents or $86.5 \%)$. The length of services teachers in teaching more than 16 years with 167 respondents (43.4\%), followed by respondents were teaching between period 6 to 10 years were 82 respondents (21.2\%), teaching between 11 to 15 years were 69 respondents (17.9\%), and the least number respondents were teaching less than 5 years with 68 respondents (17.6\%).

\subsection{Instrument}

The instrument of occupational stress used in this study is measured by the Occupational Roles Questionnaire (ORQ) adapted from Wu et al. (2010) and Occupational Stress Indicator (OSI) adapted from Chang and Lu (2009). This scale includes two elements from ORQ, namely role ambiguity and role overload which comprised 10 items for each elements. To measure work-family conflict, the Occupational Stress Indicator (OSI) was used adapted from Chang and Lu (2009) which comprised seven items. The main reason for this choice of all three elements occupational stress was widely used in previous studies. Job satisfaction is measured using the Minnesota Satisfaction Questionnaire (MSQ) adapted from Ang and Soh (1997). The MSQ measure the degree of job satisfaction consists of 20 items representing a feature in the work environment. The MSQ provides more specific information on the aspect of a job that an individual finds rewarding than do more general measures of job satisfaction.

\subsection{Data Analysis Method}

The data were analyzed using the Statistical Package for the Social Sciences (SPSS Version 16.0 for Windows). Various statistical methods have been employed in this study. These methods include descriptive analysis, Pearson correlation analysis and multiple regression analysis. To determine the level of occupational stress, the descriptive analysis was measured using percentages, frequency distribution and means score (Hair et al., 2007). The correlation was used to determine the significant relationship between two variables which is independent variables and dependent variables. In this study, Pearson correlation was used to see the relationship between occupational stress and job satisfaction. Multiple regression analysis was also used to determine the effect or impact of various independent variables on the dependent variables. These analyses enable researcher to evaluate the relative influence of occupational stress on the job satisfaction.

\section{Findings and Discussion}

\subsection{Level of occupational stress}

Table 1. Level of Occupational Stress

\begin{tabular}{|lcc|}
\hline Variables & Mean & Standard Deviation \\
\hline Occupational Stress (Overall) & 3.80 & 0.38 \\
Role Overload & 3.95 & 0.42 \\
Role Ambiguity & 4.00 & 0.67 \\
Work-Family Conflict & 3.44 & 0.49 \\
\hline
\end{tabular}

The data were analyzed using descriptive analysis is used to provide basic information on the nature of each variable in this study. It involves the calculation method using percentages, frequency distribution and mean score (Hair et al., 2007). The calculation of the mean score was used to determine the level of occupational stress.

Table 1 shows that the level of occupational stress among teachers in Malacca. Based on the feedback obtained from respondents, it can be seen that the overall level of occupational stress is high at $3.80(S D=0.38)$. Role ambiguity had highest mean which is 4.00 , followed by role overload (4.09). However, there was a moderate level of work-family 
conflict at 3.44. Overall, teachers at Malacca had reported high level of occupational stress.

\subsection{Hypothesis Testing}

To test the hypothesis the data were analyzed using Pearson correlation and multiple regression analysis. Pearson correlation was used to determine the significant relationship between two variables which is independent variable and dependent variable. Multiple regression analysis was used in this study to determine the effect or impact of various independent variables on the dependent variable. The independent variable is occupational stress and dependent variable is job satisfaction.

\subsubsection{The result of Hypothesis 1}

Table 2. Correlation between Occupational Stress and Job Satisfaction

\begin{tabular}{|lc|}
\hline Variables & Job satisfaction \\
\hline Occupational Stress (Overall) & $0.13^{\star}$ \\
Role Overload & -0.09 \\
Role Ambiguity & $0.50^{\star \star}$ \\
Work-Family Conflict & -0.03 \\
\hline
\end{tabular}

${ }^{\star} p<0.05,{ }^{* *} p<0.01$

The results on table 2 shows that overall occupational stress has a significant and positive relationship with job satisfaction $(r=0.13, p<.05)$. However, the relationship between overall occupational stress and job satisfaction is slightly weak. This means that the lower the occupational stress the higher job satisfaction among respondents. The analysis also found that only one components of occupational stress have a significant and positive relationship with job satisfaction is role ambiguity $(r=0.50, p<0.01)$. However, the relationship between role ambiguity and job satisfaction is at a moderate level. There is no significant relationship between role overload and work-family conflict with job satisfaction. This indicates that only role ambiguity have a relationship with job satisfaction. Therefore, the hypothesis H1 outlined is accepted.

\subsubsection{The result of Hyphothesis 2}

Table 3. Multiple Regression between Occupational Stress and Job Satisfaction

\begin{tabular}{|c|c|c|c|}
\hline \multirow[b]{2}{*}{ Variables } & \multicolumn{3}{|c|}{ Job Satisfaction } \\
\hline & $\mathbf{R}^{2}$ & $F$ & $\beta$ \\
\hline & $0.28^{\star \star}$ & 50.05 & \\
\hline Role Overload & & & $-0.21^{\star \star}$ \\
\hline Role Ambiguity & & & $0.51^{\star \star}$ \\
\hline work-Family Conflict & & & 0.06 \\
\hline
\end{tabular}

Table 3 shows the results of the multiple regression analysis of the effects of occupational stress on job satisfaction. The results indicated that only $28 \%$ of job satisfaction $\left(R^{2}=0.28, F=50.05, p<0.01\right)$ is significantly explained by the three components of occupational stress: role overload, role ambiguity, and work-family conflict. Only two components of occupational stress in the regression equation emerged as significant predictor of job satisfaction. The predictor is role overload $(\beta=-0.21, p<0.01)$ and role ambiguity $(\beta=0.51, p<0.01)$. Therefore, the hypothesis $\mathrm{H} 2$ outlined is partially accepted.

\section{Concluding Remarks}

In this study, occupational stress consists of role overload, role ambiguity, and work-family conflict. Based on the feedback obtained from respondents, it can be seen that the level of role ambiguity and role overload is high. However, there was a moderate level of work-family conflict. Overall, teachers at Malacca had reported high level of occupational stress. 
Although the level of occupational stress of the respondents is high, but there are also respondents who have a moderate level of occupational stress. The reason for increase in the stress level among respondents could be lack of clarity in their roles, overload of work, assignments, and relationship conflict at home and work. Besides, the high level of occupational stress is due to the response people may have when presented with work demands and pressures that aren't matched to their work knowledge and abilities which challenge their ability to cope with the problem (Mayuran, 2013). According to Nilufar et al. (2009), people with higher percentage of occupational stress may feel frustrated when they are having problems with colleagues or society and this may lead to the negative impact to the organization. They may not feel happy working and therefore may not be satisfied with their job.

The results show that overall occupational stress has a significant and positive relationship with job satisfaction. The finding suggests that higher the occupational stress by the teachers, lower will be their job satisfaction. When occupational stress is lower, this obviously will lead towards teachers' job satisfaction. Occupational stress and job satisfaction are interrelated. If a person is stressed on his job, he will experience job dissatisfaction and will not be able to be productive and affected their efficiency to deliver 100\% towards their work (Muhammad et al., 2011). Muhammad et al. (2011) indicate that there is a negative relationship between job stress and job satisfaction. Employees who had high level of job stress had low job satisfaction. The result of this study also line with Nilufar et al. (2009), Jahanzeb (2010), Bhatti et al. (2011), Muhammad et al. (2011), and Suryawanshi and Mali (2013).

It was also revealed that there is only $28 \%$ of job satisfaction is significantly explained by occupational stress. Role overload and role ambiguity emerged as significant predictor of job satisfaction. It is evident that the most influential occupational stress on job satisfaction is role ambiguity. While, role overload explained the decreased of role overload can improve the level of job satisfaction. The results in this study were is in line with Koustelios et al. (2004). The result found that role ambiguity related to job satisfaction. This is due to the individual perception that lacks of information necessary to perform a job or task given leading them to feel helpless (Onyemah, 2008). The uncertainty about the expectations is a result from inadequate information and knowledge to do a job. This study also revealed that role overload is negatively correlated with job satisfaction. This suggests that respondent who felt heavy demands made upon them are also less satisfied with their job. This findings is consistent with Kemery (2006), Correa and Ferreira (2011), and Rai (2013). Butt and Lance (2005) found that role overload was related to job satisfaction among secondary school teachers. The pressure on teachers to do more work was extent of non-teaching task such as photocopying, filing, acting as social worker, paperwork, form filing, duplicating and typing letters.

\section{References}

Ang, J. \& Soh, P.H. (1997). User Information Satisfaction, Job Satisfaction and Computer Background: An Exploratory Study. Information \& Management, 32, 255-266.

Antoniou, A-S. G., Davidson, M.J. \& Cooper, C.L. (2003). Occupational Stress, Job Satisfaction and Health State in Male and Female Junior Hospital Doctors in Greece. Journal of Managerial Psychology, 18(6), 592- 621.

Bhatti, N., Hashimi, M.A., Raza, S.A., Shaikh, F.M. \& Shafiq, K. (2011). Empirical Analysis of Job Stress on Job Satisfaction among University Teachers in Pakistan. International Business Research, 4(3), 264-270.

Brown, Z.A. \& Uehara, D.L. (2008). Coping with teacher stress: A research synthesis for Pacific Educator. Pacific Resources for Education and Learning. Retrieved November 23, 2012, from http://www.prel.org/products/.

Butt, G. \& Lance, A. (2005). Secondary Teacher Workload and Job Satisfaction. Do Successful Strategies for Change Exist?. Educational Management Administration \& Leadership, 33(4), 401-422.

Calvo-Salguero, A., Carrasco-Gonzalez, A.M. \& de Lecea, J.S.S-M. (2010). Relationship between Work-Family Conflict and Job Satisfaction: The Moderating effect of Gender and The Salience of Family and Work Roles. African Journal of Business Management, 4(7), 1247-1259.

Chang, K. \& Lu, L. (2009). The Influence of Occupation on Stressors and Work Behaviours. The International Journal of Human Resource Management, 20(3), 591-605.

Chen, T-L, Huang, M-Y, \& Su, T-H. (2012). Work Motivation, Work Stress, and Job Satisfaction in between Taiwan and China - An Empirical Study. World Academy of Science, Engineering and Technology, 68, $1446-1450$.

Correa, A.P. \& Ferreira, M.C. (2011). The Impact of Environmental Stressors and types of Work Contract on Occupational Stress. The Spanish Journal of Psychology, 14(1), 251-262.

Faucett, J.M., Corwyn, R.F., \& Poling, T.H. (2012). Clergy Role Stress: Interactive Effects of Role Ambiguity and Role Conflict on Intrinsic Job Satisfaction. Pastoral Psychology, 62(3), 291-304.

Gaither, C.A., Kahaleh, A.A., Doucette, W.R., Mott, D.A., Pederson, C.A., \&Schommer, J.C. (2008). A Modified Model of Pharmacists' Job Stress: The Role of Organizational, Extra-Role, and Individual Factors on Work-Related Outcomes. Research in Social and Administrative Pharmacy, 4, 231-243.

Hair, J.F., Money, H., Samouel, P. \& Page, M. (2007). Research methods for business. United State: John Wiley and Sons, Inc.

Holmlund-Rytkonen, M. \& Strandvik, T. (2005). Stress in the business relationship. Journal of Business \& Industrial Marketing, 20(1), 12- 
22.

Jahanzeb, H. (2010). The Impact of Job Stress on Job Satisfaction among Academic Faculty of A Mega Distance Learning Institution in Pakistan. A Case Study of Allama Iqbal Open University. Mustang Journal of Business \& Ethics, 1, 31-48.

Johnson, S., Cooper, C., Cartwright, S., Donald,I., Taylor, P., \& Millet, C. (2005). The experience of work related stress across occupation. Journal of Managerial Psychology, 20(2), 178-187.

Ili Liyana, M. (2013, August 28). Teachers burdened with administrative, clerical work, New Straits Times. [Online]. Available at http://www.nst.com

Kappagoda, S. (2013). Emotional intelligence as a predictor of work-family conflict among school teachers in North Central Province in Sri Lanka (January 5, 2013). Proceedings of the $2^{\text {nd }}$ International Conference on Management and Economic (2013), University of Ruhuna, Sri Lanka. Available at papers.ssrn.com

Karadal, H., Ay, U., \& Cuhadar, M.T. (2008). The Effect of Role Conflict and Role Ambiguity on Job Satisfaction and Organizational Commitment: A Study in the Public and Private Sector. The Journal of American Academy of Business, 13(2), 176-181.

Kemery, E.R. (2006). Clergy Role Stress and Satisfaction: Role Ambiguity Isn't Always Bad. Pastoral Psychol, 54, 561570.

Koustelios, A., Theodorakis, N., \& Goulimaris, D. (2004). Role Ambiguity, Role Conflict and Job Satisfaction among Physical Education Teachers in Greece. The International Journal of Educational Management, 18(2), 87-92.

Kyriacou, C. (2001). Teacher stress: directions for future research. Educational Review, 53(1), 27-35.

Lambert, E.G., Hogan, N.L., \& Barton, S.M. (2002). The Impact of Work-Family Conflict on Correctional Staff Job Satisfaction: An Exploratory Study. American Journal of Criminal Justice, 27(1), 35-52.

Lambert, E.G., Hogan, N.L., Elechi, O.O., Jiang, S., Laux, J.M., Dupuy, P. \& Morris, A. (2009). A further examination of antecedents of correctional staff life satisfaction. The Social Science Journal, 46, 689-706.

Leather, P., Beale, D., \& Sullivan, L. (2003). Noise, Psychosocial Stress and Their Interaction in the Workplace. Journal of Environment Psychology, 23, 213-222.

Lu, L., Kao, S-F.,Chang, T-T., Wu, H-S., \& Cooper, C.L. (2008). Work/Family Demands, Work Flexibility, Work/Family Conflict, and Their Consequences at Work: A National Probability Sample in Taiwan. International Journal of Stress Management, 15(1), 1-21.

Malaysia Education Blueprint (2012). Preliminary Report: Malaysia Education Blueprint 2013-2025.[Online] Retrieved from www.moe.gov.my

Mayuran, L. (2013). Impact of emotional intelligence on stress management: Study of Schools with Banks in Jaffna District. Global Journal of Commerce and Management Perspective, 2(6), 67-71.

Mehta, A. (2013). A study of how emotional intelligence reduces occupational stress among teachers. International Monthly Refereed Journal of Research in Management and Technology, 19-28. Retrieved from www.abhinavjournal.com

Mohd Adib, P. (2012, November 4). 237 teachers seek psychiatric help. New Straits Times.

Muhammad, M., Sabtain, F., Saima, N., \& Zubair, A. (2011). The impact of job stress on employee job satisfaction: A study on telecommunication sector of Pakistan. Journal of Business Studies Quarterly, 2(3), 50-56.

Nilufar, A., Zaini, A., David, Y.G.F., \& Syed, S.A. (2009). A Study of Job Stress on Job Satisfaction among University Staff in Malaysia: Empirical Study. European Journal of Social Sciences, 8(1), 121-131.

Nurul, I.A.S., Zailina, H., Saidi, M. \&Haslinda, A. (2010). Assessment of stress and its risk factors among primary school teachers in the Klang Valley, Malaysia. Global Journal of Health Science, 2(2), 163-171.

Oginska-Bulik, N. (2005). Emotional intelligence in the workplace: exploring its effects on occupational stress and health outcomes in human service workers. International Journal of Occupational Medicine and Environmental Health, 18(2), 167-175.

Rai, G.S. (2013). Job Satisfaction Among Long-Term Care Staff: Bureaucracy Isn't Always Bad. Administrative in Social Work, 37(1), 9099.

Rutra, S. (2011). Teachers fume over new directive, Free Malaysia Today. [Online]. Available at http://www.freemalaysiatoday.com

Simbula, S. (2010). Daily Fluctuations in Teachers' Well-being: A Diary Study Using the Job Demands-Resources Model, Anxiety, Stress \& Coping. An International Journal, 23(5), 563-584.

Suryawanshi, S.A. \& Mali, V.J. (2013). A Study on Relationship between Organizational Role Stress and Job Satisfaction. Indian Journal of Research, 2(2), 212-214.

Sveinsdottir, H., Biering, P. \& Ramel, A. (2006). Occupational Stress, Job Satisfaction, and Working Environment among Icelandic Nurses: A Cross-Sectional Questionnaire Survey. International Journal of Nursing Studies, 43, 875-889.

Sweeney, J.T. \& Quirin, J.J. (2009). Accountants as layoff survivors: A research note. Accounting, organizations and society, 34, 787795.

Topper, E.F. (2007). Stress in the library. Journal of New Library, 108(11/12), 561-564.

Usman, A., Ahmed, Z., Ahmed, I. \&Akbar, Z. (2011). Work stress experienced by the teaching staff of University of the Punjab, Pakistan: Antecedents and consequences. International Journal of Business and Social Science, 2(8), 202-210.

Wu, H., Zhao, Y., Wang, J-N., \& Wang, L. (2010). Factors Associated with Occupational Stress among Chinese Doctors: A CrossSectional Survey. International Archives of Occupational and Environmental Health, 83(2), 155-164.

Zainudin, A., Junaidah, H.A., \& Nazmi, M.Z. (2010). Modeling Job Satisfaction and Work Commitment Among Lecturers: A Case of UITM Kelantan. Journal of Statistical Modeling and Analytics, 1(2), 45-59. 